\title{
An empirical examination of individual and system characteristics on enhancing e-learning acceptance
}

\author{
Yi-Hsuan Lee \\ National Central University, Taiwan \\ Chan Hsiao \\ National Chiao Tung University, Taiwan \\ Sutrisno Hadi Purnomo \\ Sebelas Maret University, Indonesia
}

\begin{abstract}
Due to the continued prevalence of e-learning underutilization in Indonesia's higher education context, this study empirically examines individual and system characteristics believed to influence students' acceptance of e-learning systems. The proposed research model is developed to examine the influence of five characteristics of the Technology Acceptance Model using the Structural Equation Modelling technique. This study found that both individual characteristics, computer self-efficacy and internet self-efficacy, play an important role, indirectly affecting perceived intention to use e-learning. The system characteristics including learning content and technology accessibility have been found to significantly influence learners' acceptance behaviours. Both perceived ease of use and perceived usefulness were found to be significant predictors of perceived intention to use. Additionally, perceived usefulness was found to have more predictive power than perceived ease of use on behavioural intention to use. This study contributes to a better understanding of how to enhance e-learning acceptance through improvement in individual and system characteristics.
\end{abstract}

\section{Introduction}

Organisations have recently struggled to adjust fully to the changing global environment and enhance their competitiveness. In line with the development of information communication technologies (ICT) and the internet, numerous organisations, including educational institutions, are using electronic learning, or e-learning. ICT in teaching and learning has generated a need to transform the way in which higher education students learn by using more modern, efficient, and effective alternatives. One such alternative is e-learning, referring to the use of computer network technology to deliver a broad array of solutions (typically over an intranet or the internet) that enhance knowledge (Welsh, Wanberg, Brown \& Simmering, 2003; Engelbrecht, 2005; Yuen \& Ma, 2008). E-learning also uses web-based communication, collaboration, knowledge transfer, and training to process asynchronous or self-paced learning without time and space barriers (Kelly, 2001; Kelly \& Bauer, 2004; Lee, Yoon \& Lee, 2009; Yuen \& Ma, 2008; Cheng, 2011). The emergence of computer tablets with portability, an abundance of multimedia applications, and multiple routes for internet access also extend e-learning applications (Kinash, Brand \& Mathew, 2012). Numerous higher education institutions have therefore adopted webbased learning systems for their e-learning courses. E-learning systems enable learners to independently study course contents. They can also decide when to study, the sequence of the study content, and the amount of time to spend on self-education, without time and space barriers (Blake \& Butcher-Green, 2009).

Education delivered through electronic media is becoming increasingly relevant in educational systems, particularly at the tertiary level. Developing countries are increasingly using e-learning systems, which are proving to be beneficial in educational institutions. In the case of Indonesia, the development of ICT is less encouraging compared with developed countries, or neighbouring developing countries, such as Malaysia, the Philippines, and Thailand (Yuhetty, 2003). Kuntoro and Al-Hawamdeh (2003) found that the level of participation in e-learning courses is low and that the quality of such courses is perceived as only fair. Abbad, Morris and Nahlik (2009) argued that successful implementation of an e-learning system requires in-depth understanding of user acceptance processes and methods of engaging students with these technologies (Saadé\&Bahli, 2005). However, Ngai, Poon and Chan (2007) indicated a limited empirical examination of factors underlying student adoption of e-learning systems. Thus, we investigate 
what external factors to consider in enhancing e-learning acceptance. Numerous constraints affect the total acceptability of this technology. Soekartawi (2005) identified four constraints influencing e-learning acceptance in developing countries, including ICT infrastructure, human resources, pedagogical aspects, and policy support. Human factors are a crucial factor in facilitating diffusion of an ICT program, such as e-learning in most developing countries (Yuhetty, 2003; Purnomo \& Lee, 2010). Therefore investigating human factors affecting acceptance of e-learning systems in Indonesia is a prime concern.

Numerous problems relate to human factors in developing countries, including general poor ICT knowledge and skills, a lack of understanding of the Internet among instructors and students, and negative attitudes toward e-learning systems (Soekartawi, 2005). For student attitudes toward e-learning, Kuntoro and Al-Hawamdeh (2003) highlighted the passive nature of Indonesian students' learning habits, leading to e-learning problems because of the requirement of this mode of learning for students to be more involved and explorative. Therefore serious effort must be made to overcome this problem and to enhance e-learning acceptance in Indonesian higher institutions. Research is required to more intensively focus on student perceptions and attitudes toward e-learning and their intention to use such a learning approach.

The three variables of perceived usefulness (PU), perceived ease of use (PEOU), and perceived intention to use (PIU) are combined as the basis of the technology acceptance model (TAM),(Davis, 1989), which has been used as the theoretical foundation for numerous empirical studies to research user technology acceptance (Venkatesh \& Davis, 2000; Seyal, Rahman \& Rahmim, 2002). However, a critical review of TAM (Legris, Ingham \& Collerette, 2003; Wu \& Wu, 2005) argued that there is a need to incorporate other external and internal variables to provide a comprehensive view of IT adoption behaviour. Okazaki and dos Santos (2012) proposed that attempts to extend the TAM have adopted one of three approaches: introducing variables from related models, introducing additional or alternative factors, and examining antecedents and moderators of PU and PEOU (Wixom \& Todd, 2005). Specific factors related to human change processes should be incorporated to search for more external variables to provide increasingly accurate explanations of the TAM model (Csikszentmihalyi, 1993; Cheng, 2011). We use the two critical dimensions of individual and system characteristics as external variables in the TAM to obtain results. For individual characteristics, certain literature and empirical studies have highlighted the importance of psychological readiness for the computer and Internet during e-learning implementation in Indonesia's higher-education context (Pannen \& Abubakar, 2005; Kuntoro \& Al-Hawamdeh, 2003; Ali, 2004; Hussein, Aditiawarman \& Mohamed, 2007). Thus, we propose the three external variables of computer self-efficacy, internet self-efficacy, and instructor's attitude toward students to be the primary aspects of individual characteristics affecting e-learning acceptance in Indonesia (Pannen \& Abubakar, 2005; Priyanto, 2007: Basuki, 2007). For system characteristics, course management and technology factors have been observed to be the primary problems in fostering e-learning in developing countries (Kuntoro \& Al-Hawamdeh, 2003; Soekartawi, 2007; Andersson \& Grönlund, 2009). Therefore we select learning content and technology accessibility as external variables affecting e-learning acceptance in Indonesia.

In sum, we employ two dimensions of five external variables to achieve the aim of this study: computer self-efficacy, internet self-efficacy, instructor's attitude toward students, learning content, and technology accessibility. We tested these five external variables combined with the TAM, PU, PEOU, and IU in the proposed model using structural equation modelling (SEM). We hope to identify the influence of individual and system characteristics on the perception of usage intention with respect to e-learning systems. We anticipate that our research model will assist information system researchers and practitioners to better clarify individual and system characteristics in the development, management, and use of new ICT. Therefore we explore the e-learning acceptance of students drawn from two public universities in Indonesia, and are guided by the following research questions:

1. What external factors should be considered in enhancing e-learning acceptance?

2. To what extent does the individual characteristic of external factors influence e-learning acceptance?

3. To what extent does the system characteristic of external factors influence e-learning acceptance? 


\section{Theoretical frameworks and hypothesis development}

Recently, the technology acceptance model has been applied to understand learners' acceptance of elearning systems (e.g., Ong, Lai \& Wang, 2004; Lee, 2006; Ong \& Lai, 2006; Hussein et al., 2007; Park, et al., 2009). The TAM introduces two particular beliefs: perceived usefulness (PU) and perceived ease of use (PEOU), which are the important antecedents of behavioural intentions to use information technology. PU is defined as "the degree to which a person believes that using a particular system would enhance job performance", while PEOU is defined as "the degree to which a person believes that using a particular system would be free of physical and mental effort"' (Davis, 1989). Further, PU and PEOU both affect a person's attitude toward using a technology system and these attitudes determine the behavioural intentions to use the system, which, in turn, lead to actual system usage.

In the revised version, the TAM was extended by incorporating a variety of external variables (Venkatesh \& Davis, 1996, 2000; Venkatesh, 2000; Venkatesh \& Morris, 2000; Venkatesh, et al., 2003). It was suggested that other external variables affecting users' acceptance behaviour of a new technology are mediated by the two constructs, PU and PEOU; however, the empirical evidence for such external variables were not tested by them at that time. In this line of TAM research, several external variables were identified in addition to PU and PEOU to explicate the determinants of users' acceptance decisions on e-learning systems (Pan, Sivo \& Brophy, 2003; Saadé \& Bahli, 2005; Volery \& Lord, 2000; Brown, 2002; Hussein et al., 2007; Park et al., 2009; Lau \& Woods, 2009). For example, some researchers (Brown, 2002; Pituch \& Lee, 2006) identified two sets of external variables that affect PEOU and PU of an e-learning system: (1) individual characteristics; and (2) system characteristics. Accordingly, this study investigates the impact of external variables that include individual characteristics and system characteristics on users' perceived ease of use, usefulness, and intention to use e-learning systems in an attempt to investigate users' acceptance behaviour with respect to e-learning systems. Our research model (See Figure 1), which integrated the key belief dimensions of the TAM, was tested with antecedents found to be important predictors of the use beliefs (PU and PEOU) in e-learning systems acceptance. This model assumed that two individual characteristics and three system characteristics would directly affect both use beliefs (PU and PEOU). The impact of the antecedent variables on perceived intention to use (PIU) was hypothesized to be completely mediated by PU and PEU. As mentioned in the TAM model, PEOU would directly affect PU and both PU and PEOU would affect PIU of e-learning systems.

\section{Computer self-efficacy}

Computer self-efficacy is defined as individuals' beliefs about their ability to use a computer in the context of information technology (IT) usage (Compeau \& Higgins, 1995; Compeau, Higgins \& Huff, 1999). Empirical studies show that computer self-efficacy influences technology acceptance (Burkhardt \& Brass, 1990; Igbaria \& Ivari, 1995) and several findings have demonstrated the significance of computer self-efficacy in explaining users' computing behaviours (Vankatesh \& Davis, 1996; Fenech, 1998). Computer self-efficacy plays a critical role in terms of its effect on PEOU (Madorin \& Iwasiw, 1999) and PU (Venkatesh \& Davis, 1996; Hayashi, Chen, Ryan \& Wu, 2004). In the context of Indonesia, Pannen and Abubakar (2005) have indicated that there are serious problems in terms of psychological readiness, such as student self-efficacy in an e-learning situation. An empirical study by Hussein et al. (2007) demonstrated that computer self-efficacy is an important determinant of e-learning acceptance in Indonesia's Open University. These indications suggest that computer self-efficacy has a significant effect on PEOU and PU for an e-learning system. Thus, we make the following hypotheses:

H1: Computer self-efficacy has a positive effect on PU of an e-learning system.

H2: Computer self-efficacy has a positive effect on PEOU of an e-learning system.

\section{Internet self-efficacy}

Internet self-efficacy refers to an individual's belief in his or her ability to successfully perform a distinct set of behaviours required to establish, maintain, and effectively utilize the Internet over and above basic personal computer skills (Eastin \& LaRose, 2000). Joo, Bong and Choi (2000) defined internet selfefficacy as the perceived capability to use the Internet. Some researchers (Joo Bong and Choi, 2000; Eastian \& LasRose, 2000; Hsu \& Chiu, 2004) have found that internet self-efficacy is one predictor of the 
intention to directly or indirectly use the internet. Specifically, Roca, et al. (2006) proved that internet self-efficacy is a significant predictor of PEOU. In accordance with previous research, this study proposes that internet self-efficacy is a predictor of behaviour intention to use indirectly via PU. Therefore, we hypothesize that:

H3: Internet self-efficacy has a positive effect on the PU of an e-learning system.

H4: Internet self-efficacy has a positive effect on the PEOU of an e-learning system.

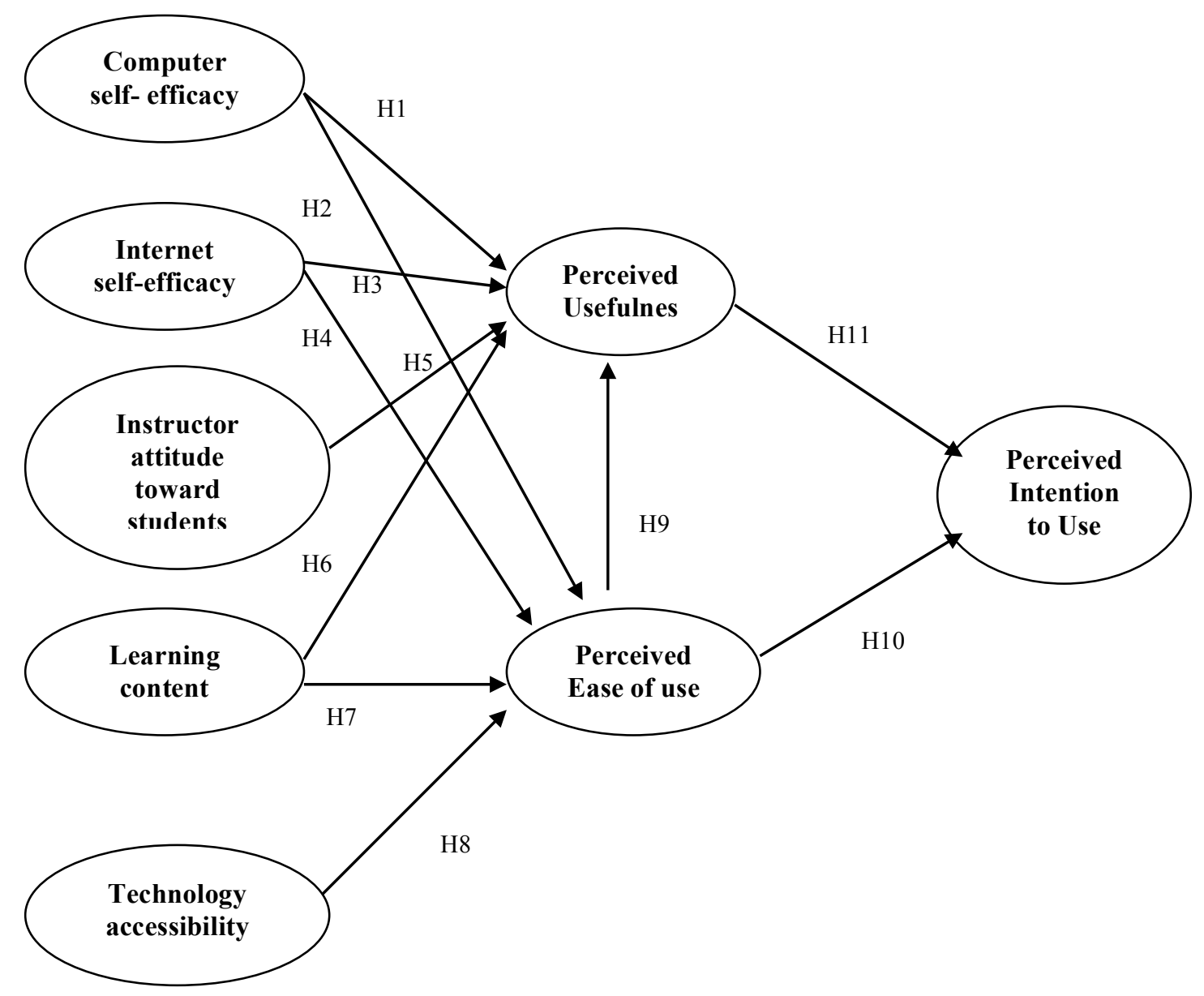

Figure 1.The proposed research model

\section{Instructor's attitude toward students}

Collis (1995) remarked that an instructor plays a central role in the effectiveness of e-learning acceptance. Volery and Lord (2000) noted that an instructor's attitude toward students is related to the instructor's personal approach and teaching manner, and their ability to motivate the students in a classroom setting during intensive learning. Additionally, Volery and Lord (2000) explored three critical factors in elearning acceptance: technology (ease of access and navigation, interface design, and level of interaction); instructor (attitudes towards students, instructor's technical competence, and classroom interaction); and previous use of technology from a student's perspective. Serwatka (1999) emphasized that students attending a class with an instructor who has a positive attitude towards learning delivery and who promotes the technology are likely to experience more positive learning outcomes. Therefore, based upon the results of previous research, we propose that instructor's attitude toward students is a predictor of PU. We examine this through the following hypothesis:

H5: Instructor's attitude toward students has a positive effect on PU of an e-learning system. 


\section{Learning content}

Online learning content refers to the content of a learning program (Lim, Lee \& Nam, 2007). According to Barker (2003), the design of online learning should be similar in fashion to a classroom format in terms of the course description, objectives, learning content, purpose, scope and evaluation. Picciano (2001) argued that media without content is powerless. He went on to emphasize that a message must be tailored to the delivery method; some media are better suited for delivering specific forms of information. Furthermore, he suggested that interaction and communication from instructor-to-student and student-tostudent must be carefully considered in designing and developing learning content. In the context of Indonesia, Soekartawi (2005) found that the problems in designing, developing, and administering an online learning program still remained. An empirical study by Hussein et al. (2007) demonstrated that design and layout of the e-learning management systems seems to have a positive effect on students' acceptance of online learning in Indonesia. Thus having well-designed e-learning content may facilitate online learning and increase motivation to use the e-learning tools. In light of this, we assert that learning content is an important determinant that directly influences users' PU and PEOU. Thus, we propose the following hypotheses:

H6: Learning content has a positive effect on the PU of an e-learning system.

H7: Learning content has a positive effect on the PEOU of an e-learning system.

\section{Technology accessibility}

Accessibility is defined as the degree of convenience with which an individual accesses an information system (Park et al., 2009). Christensen, Anakwe and Kessler (2001) clarified that technology accessibility is also important in that distance learners will have to access the technology used in an online learning course. Previous research (Graham, 1995; Harter \& Kim, 1996; Zhang \& Estabrook, 1998) found that greater accessibility leads to more frequent use of an information system, whereas low accessibility works as a barrier in using the system. Soekartawi (2005) reported that students in developing countries encounter the problem of connectivity. Such problems are associated with the availability of telephone lines, electricity, and internet connections. Poon, Low and Yong (2004) strengthened this claim by noting that problems with connectivity and low browsing speeds will deter students from taking online courses. Therefore, technology must be designed and managed carefully in order to meet the basic demands of an online learning system. Hussein et al. (2007) found that technological factors are a significant predictor of PEOU. Lin and $\mathrm{Lu}$ (2000) reported that easier information accessibility brings about higher use of information and higher perceptions of ease of use. Similarly, Park (2009) found system accessibility of technology to be significant with respect to PEOU. Based upon the preceding research, the following hypothesis is proposed:

H8: Technology accessibility has a positive effect on the PEOU of an e-learning system.

\section{Perceived usefulness, perceived ease of use and perceived intention to use}

Numerous empirical studies have provided support for the proposition that PU and PEOU are the primary predictors of PIU an information technology system (Davis, 1989; Igbaria, Zinatelli, Cragg \& Cavaye, 1997; Gefen \& Straub, 1997, 2000; Venkatesh \& Davis, 2000; Gefen, 2003; Ong et al., 2004; Lee, 2006; Ong \& Lai, 2006; Hussein et al., 2007; Park et al., 2009). In the context of e-learning, PU refers to the extent to which students believe that using the e-learning system will enhance their learning performance, while PEOU is defined as the degree to which a student believes that the use of an e-learning system will be effortless and easy to use (Davis, 1989). PEOU will similarly directly or indirectly affect a student's intention to adopt e-learning through their PU. Thus based on the above, we make the following hypotheses:

H9: PEOU has a positive effect on PU of an e-learning system.

H10: PEOU has a positive effect on the PIU of an e-learning system.

H11: PU has a positive effect on PIU of an e-learning system. 


\section{Research methods}

\section{Sample description}

The data used to examine the research model were obtained from two public universities in Indonesia, located on Central Java Island, and representative of the 10 largest campuses applying the e-learning system in Indonesia. These two universities possess various faculties that are traditionally found in universities such as medicine, engineering, agriculture, science, education, economics and business, law, literature, and social sciences. Therefore, these universities constitute an appropriate sample for this research.

\section{E-learning context}

Since 2000, universities have created ICT roles for learning activities, developing learning management systems (LMSs) to support e-learning. In Indonesia, e-learning is typically implemented in higher education to support administrative works, management, laboratories, digital libraries, and learning activities. The e-learning implementation model facilitates two primary functions: face-to-face interactions between students and lecturers (interactive in-class activities) and student self-study (in laboratories and libraries, and providing expert consultations). The LMS allows two types of interface access: student-desk and lecturer-desk LMS access. The students' LMS involves features such as My Class, providing a timetable for each course, the names of classmates, and the contents of the textbook. The LMS also allows the academic administration direct access to information services, facilitating accurate information releases. Lecturers can use the LMS to obtain information regarding their students and access information services. Both students and lecturers can access the comprehensive My Class function, which provides schedules and module plans, downloads (e.g., lecture materials, presentation files, support materials, video animations, assignments), discussion forums, answer-uploading (for students), student assignment summaries (for lecturers), and supplementary assignments (when lecturers provide additional materials). In summary, LMSs provide an e-learning environment enabling students and lecturers to learn and exchange information and facilitate learning. Because LMSs are easy to access, widely accepted, and prevalently used, LMSs are often compulsory for both students and lecturers at universities.

\section{Questionnaire collected}

The questionnaire was designed as an online survey placed on the university e-learning system. The questionnaire was administered through the LMS used by the universities and only registered students could access the questionnaire. The link to the online survey was sent by e-mail to a total of 500 students who had taken at least one e-learning course offered by the two universities and various faculties. We received a total of 355 responses. Since 29 questionnaires were incomplete, a total of 326 usable questionnaires were used, representing a response rate of $65 \%$.

To provide better insight into the participants, respondent demographic profiles, including gender, age and education, were analyzed. In this study, there were more male respondents $(56.4 \%)$ than female. The majority of respondents $(53.4 \%)$ were in the $20-30$ age range, with $42 \%$ falling into the less than 20 years of age category. In terms of educational level, the highest level was bachelor's degree (74.8\%), followed by vocational degree $(21.2 \%)$, master's degree $(2.8 \%)$ and finally doctoral degree $(1.2 \%)$. Most participants had internet experience of more than 3 years, representing $62.6 \%$ of the total sample. $50.6 \%$ of the respondents reported less than 1 year of e-learning experience. These sample demographics are recorded in Table 1. 
Table 1

Respondents Demographic Profiles $(\mathrm{N}=326)$

\begin{tabular}{|c|c|c|c|}
\hline \multicolumn{2}{|l|}{ Variables } & \multirow{2}{*}{$\frac{\text { Frequency }}{184}$} & \multirow{2}{*}{$\frac{\text { Percent }}{56.4}$} \\
\hline Gender & Male & & \\
\hline & Female & 142 & 43.6 \\
\hline \multirow[t]{5}{*}{ Age } & $<20$ year & 137 & 42.0 \\
\hline & 20-30 year & 174 & 53.4 \\
\hline & $30-40$ year & 11 & 3.4 \\
\hline & $40-50$ year & 3 & 0.9 \\
\hline & $>50$ year & 1 & 0.3 \\
\hline \multirow[t]{4}{*}{ Degree of education } & Vocational & 69 & 21.2 \\
\hline & Bachelor & 244 & 74.8 \\
\hline & Master & 9 & 2.8 \\
\hline & Doctor & 4 & 1.2 \\
\hline \multirow[t]{3}{*}{ Internet experience } & $<1$ year & 16 & 4.9 \\
\hline & 1-3 year & 106 & 32.5 \\
\hline & $>3$ year & 204 & 62.6 \\
\hline \multirow[t]{3}{*}{ e-learning experience } & $<1$ year & 165 & 50.6 \\
\hline & 1-3 year & 139 & 42.6 \\
\hline & $>3$ year & 22 & 6.8 \\
\hline
\end{tabular}

\section{Instrument development}

The completed instrument consisted of two parts. Part A was designed to identify demographic attributes of the respondents. It contained demographic items such as gender, age, education level, years of using the internet, and years of e-learning experience. The instruments in part B were mainly adapted from relevant previous studies. All items were measured using a five-point Likert-type scale with anchors from strongly disagree to strongly agree. Computer self-efficacy was measured by three-items adapted from Compeau \& Higgins (1995). Four items for measuring internet self-efficacy were adapted from Roca et al. (2006). Four items for measuring instructor's attitude toward students and three items for measuring technology accessibility were adapted from Volery \& Lord (2000). Learning content as an external variable was measured mainly by adapting scales designed by Lim et al. (2007). Items for PU and PEOU were adapted from prior work by Venkatesh \& Morris (2000), while PIU items were adapted from Roca et al. (2006). The questionnaire was provided to respondents in the Indonesian language. Back-translation was conducted to translate the original English instrument into Indonesian (Brislin, 1980). One of the authors (fluent in Indonesian) translated the original instruments and a colleague back-translated the Indonesian version to English. After this iterative process, the Indonesian version was revised to finalize the instrument. The questionnaire is available upon request from the corresponding author.

\section{Results}

\section{Measurement validation}

In this study, scale reliability and validity were assessed via confirmatory factor analysis (CFA). Convergent validity of scale items was estimated by reliability, composite reliability, and average variance extracted (AVE) (Fornell \& Larcker, 1981). The standardized CFA loadings for most scale items exceeded the minimum loading criterion of 0.70 . Even though the seven items failed to meet the recommended minimum level, their value range from 0.6-0.7 was close enough to suggest that the measurement was reasonably good (Ong \& Lai, 2006; Ngai et al., 2007). The composite reliabilities of all factors also exceeded the recommended 0.70 level. Table 2 shows that the AVE values surpassed the threshold value of 0.50 , ranging from 0.503 to 0.756 (Hair, Anderson, Tatham \& Black, 1998). According to Jiang, Klein and Carr (2002), the AVE estimates normally can be found to be below 0.5 even when reliabilities are acceptable. Therefore we concluded that all constructs in the model had adequate 
convergent validity. Discriminant validity was obtained by comparing the shared variance between factors with the square root of AVE (values in the diagonal of Table 3 ) for the individual factors (Fornell $\&$ Larcker, 1981). This analysis indicated that the shared variances between the factors $(0.280-0.670)$ were less compared with the square root of the AVE (0.709-0.869) values of the individual factors. Thus discriminate validity was assured (See Table 3 ).

Table 2

Mean, Standard Deviation and Convergent Validity Analysis $(n=326)$

\begin{tabular}{|c|c|c|c|c|c|c|}
\hline Constructs/Factors & Indicators & Mean & $\begin{array}{l}\text { Standard } \\
\text { Deviation }\end{array}$ & $\begin{array}{c}\text { Standardized } \\
\text { Loading }\end{array}$ & $\begin{array}{l}\text { Composite } \\
\text { Reliability }\end{array}$ & AVE \\
\hline Computer Self- & CSE 1 & 3.45 & 0.933 & 0.692 & & \\
\hline \multirow[t]{2}{*}{ Efficacy } & CSE 2 & 2.99 & 0.948 & 0.767 & & \\
\hline & CSE 3 & 3.24 & 0.854 & 0.664 & 0.751 & 0.503 \\
\hline Internet Self- & ISE 1 & 3.16 & 0.836 & 0.670 & & \\
\hline \multirow[t]{3}{*}{ Efficacy } & ISE 2 & 3.43 & 0.904 & 0.725 & & \\
\hline & ISE 3 & 3.22 & 0.908 & 0.686 & & \\
\hline & ISE 4 & 3.33 & 0.820 & 0.796 & 0.812 & 0.520 \\
\hline Instructor's attitude & IATS 1 & 3.10 & 0.963 & 0.762 & & \\
\hline \multirow[t]{3}{*}{ Toward students } & IATS 2 & 3.13 & 0.909 & 0.794 & & \\
\hline & IATS 3 & 3.24 & 0.851 & 0.781 & & \\
\hline & IATS 4 & 3.25 & 0.812 & 0.822 & 0.869 & 0.624 \\
\hline \multirow[t]{3}{*}{ Learning content } & LC 1 & 3.40 & 0.845 & 0.728 & & \\
\hline & LC 2 & 3.36 & 0.850 & 0.816 & & \\
\hline & LC 3 & 3.43 & 0.811 & 0.702 & 0.794 & 0.563 \\
\hline Technology & TA 1 & 3.35 & 1.032 & 0.679 & & \\
\hline \multirow[t]{3}{*}{ Accessibility } & TA 2 & 2.69 & 1.022 & 0.791 & & \\
\hline & TA 3 & 2.71 & 0.997 & 0.774 & & \\
\hline & TA 4 & 3.24 & 0.894 & 0.660 & 0.818 & 0.530 \\
\hline \multirow[t]{4}{*}{ Perceived usefulness } & PU 1 & 3.37 & 0.804 & 0.839 & & \\
\hline & PU 2 & 3.37 & 0.776 & 0.871 & & \\
\hline & PU 3 & 3.38 & 0.821 & 0.914 & & \\
\hline & PU 4 & 3.50 & 0.776 & 0.851 & 0.925 & 0.756 \\
\hline \multirow{5}{*}{$\begin{array}{l}\text { Perceived ease of } \\
\text { use }\end{array}$} & PEOU 1 & & & & & \\
\hline & & 3.44 & 0.820 & 0.626 & & \\
\hline & PEOU 2 & 3.48 & 0.829 & 0.862 & & \\
\hline & PEOU 3 & 3.42 & 0.799 & 0.863 & & \\
\hline & PEOU 4 & 3.31 & 0.779 & 0.709 & 0.853 & 0.596 \\
\hline \multirow{3}{*}{$\begin{array}{l}\text { Perceived intention } \\
\text { to use }\end{array}$} & PIU 1 & 3.48 & 0.795 & 0.873 & & \\
\hline & PIU 2 & 3.49 & 0.844 & 0.862 & & \\
\hline & PIU 3 & 3.54 & 0.920 & 0.777 & 0.876 & 0.703 \\
\hline
\end{tabular}




\section{Descriptive statistics and correlation between constructs}

Table 3 presents the means, standard deviations and bivariate correlations among the study variables. Among the five external variables, learning content was found to have the highest mean $M=3.39$ $(\mathrm{SD}=.701)$, while the lowest mean was technology accessibility $M=2.99(\mathrm{SD}=.762)$. There was significant correlation among external variables with the correlation coefficients ranging from .247 to $.434(p<.01)$. There was also significant correlation between the external variables and the TAM construct with the correlation coefficients ranging from .330 to $.558(p<.01)$. Positive correlation coefficients were found among the TAM construct with correlation coefficients ranging from .386 to .670 $(p<.01)$.

Table 3

Means, Standard Deviations and Inter Construct Correlations $(n=326)$

\begin{tabular}{|c|c|c|c|c|c|c|c|c|c|c|}
\hline Construct & Mean & $\mathrm{SD}$ & 1 & 2 & 3 & 4 & 5 & 6 & 7 & 8 \\
\hline 1. Computer self-efficacy & 3.23 & .745 & .709 & & & & & & & \\
\hline 2. Internet self-efficacy & 3.28 & .663 & .347 & .721 & & & & & & \\
\hline $\begin{array}{l}\text { 3. Instructor's attitude toward } \\
\text { Students }\end{array}$ & 3.18 & .748 & .280 & .434 & .790 & & & & & \\
\hline 4. Learning content & 3.39 & .701 & .335 & .410 & .379 & .750 & & & & \\
\hline 5. Technology accessibility & 2.99 & .762 & .324 & .335 & .247 & .337 & .728 & & & \\
\hline 6. Perceived usefulness & 3.41 & .717 & .330 & .458 & .420 & .588 & .386 & .869 & & \\
\hline 7. Perceived ease of use & 3.41 & .668 & .430 & .408 & .329 & .510 & .398 & .599 & .772 & \\
\hline 8. Perceived intention to use & 3.50 & .762 & .424 & .493 & .368 & .544 & .370 & .670 & .585 & .838 \\
\hline
\end{tabular}

Note: Diagonals represent the square roots of AVE and the other matrix entries are the factor correlations.

\section{Evaluation of the structural model and hypothesis testing}

SEM approach was adopted to test the fit between the research model and the obtained data. This technique was chosen for its ability to simultaneously examine a series of dependence relationships, especially when there are direct and indirect effects among the constructs within the model (Hair et al., 1998). In this study, Amos 6.0 was used and the SEM estimation procedure used was maximum likelihood estimation. A similar set of fit indices was used to examine the structural model. Comparison of all fit indices with their corresponding recommended values provided evidence of an acceptable model fit $(\chi 2 / \mathrm{df}=587 / 351=1.67, \mathrm{p}<.00, \mathrm{GFI}=0.89, \mathrm{AGFI}=0.87, \mathrm{CFI}=0.96$, and RMSEA $=0.05)$. There was one exception where the GFI and AGFI values were slightly below the desired level of 0.90 . However, it was close enough to suggest that the model fit was reasonably adequate to assess the results for the structural model (Ong \& Lai, 2006; Ngai et al., 2007). Therefore, we concluded that the goodness of fit indices fulfilled the recommended levels, suggesting that the research model provided a good fit to the data.

The next step in the data analysis was to examine the significance and strength of hypothesized relationships in the research model (Figure 2). The results of the hypotheses testing, including standardized direct (path coefficients), indirect, total effects, path significances and variance explained ( $R^{2}$ values), for each dependent variable are presented in Table 4 . The results of path analysis are also depicted in Figure 2 with significant paths denoted with bold lines and insignificant paths with dashed lines. Starting from PU, computer self-efficacy and instructor's attitude toward students had no significant relationship with PU. As expected, Internet self-efficacy $(\beta=.16, p<.05)$, learning content $(\beta=.37, p<$ $.001)$ and PEOU $(\beta=.34, p<.001)$ had a significant, positive relationship with PU. These determinants explained approximately 59\% of the variance in PU, thus supporting hypotheses H3, H6 and H9. 
Table 4

Standardized Causal Effects for the Structural Model $(n=326)$

\begin{tabular}{|c|c|c|c|c|c|}
\hline \multirow{2}{*}{ Endogenous Variable } & \multirow{2}{*}{ Determinant } & \multicolumn{3}{|c|}{ Standardized causal effect } & \multirow{2}{*}{ Result } \\
\hline & & Direct & Indirect & Total & \\
\hline Perceived Usefulness & H1--CSE & -0.041 & 0.09 & 0.049 & Not supported \\
\hline \multirow[t]{5}{*}{$(\mathrm{R} 2=0.594)$} & H3--ISE & $* 0.165$ & 0.044 & 0.208 & Supported \\
\hline & H5--IATS & 0.100 & & 0.100 & Not Supported \\
\hline & H6--LC & $* * * 0.369$ & 0.134 & 0.503 & Supported \\
\hline & H9--PEOU & $* * * 0.336$ & & 0.336 & Supported \\
\hline & TA & & 0.046 & 0.046 & \\
\hline Perceived Ease of Use & H2--CSE & $* * * 0.268$ & & 0.268 & Supported \\
\hline \multirow[t]{3}{*}{$(\mathrm{R} 2=0.523)$} & H4--ISE & $* 0.129$ & & 0.129 & Supported \\
\hline & H7--LC & $* * * 0.398$ & & 0.398 & Supported \\
\hline & H8--TA & $* 0.138$ & & 0.138 & Supported \\
\hline Perceived Intention to Use & H11--PU & $* * * 0.517$ & & 0.517 & Supported \\
\hline \multirow[t]{6}{*}{$(\mathrm{R} 2=0.627)$} & H10--PEOU & $* * * 0.348$ & 0.174 & 0.522 & Supported \\
\hline & CSE & & 0.119 & 0.119 & \\
\hline & ISE & & 0.153 & 0.153 & \\
\hline & IATS & & 0.045 & 0.045 & \\
\hline & $\mathrm{LC}$ & & 0.398 & 0.398 & \\
\hline & TA & & 0.072 & 0.072 & \\
\hline
\end{tabular}

With respect to PEOU, the entire determinant had a positively significant relationship on this endogenous variable. As computer self-efficacy $(\beta=.27, p<.001)$, Internet self-efficacy $(\beta=.13, p<.05)$, learning content $(\beta=.40, p<.001)$ and technology accessibility $(\beta=.14, p<.05)$ had positive relationships with PEOU, hypotheses $\mathrm{H} 2, \mathrm{H} 4, \mathrm{H} 7$ and $\mathrm{H} 8$ were supported. These determinants explained approximately $52 \%$ of the variance in PEOU. With regard to PIU of an e-learning system, approximately $63 \%$ of the variance could be explained by PU $(\beta=.52, p<.001)$ and PEOU $(\beta=.35, p<.001)$. The major determinant was PU with a total influence of 0.52 , attributed purely to the direct relationship. The second determinant was PEOU with a total influence of 0.35 , again, mainly due to the direct relationship (0.34) but also in part a consequence of the indirect relationship (0.18). Therefore, hypotheses H10 and H11 were supported. 


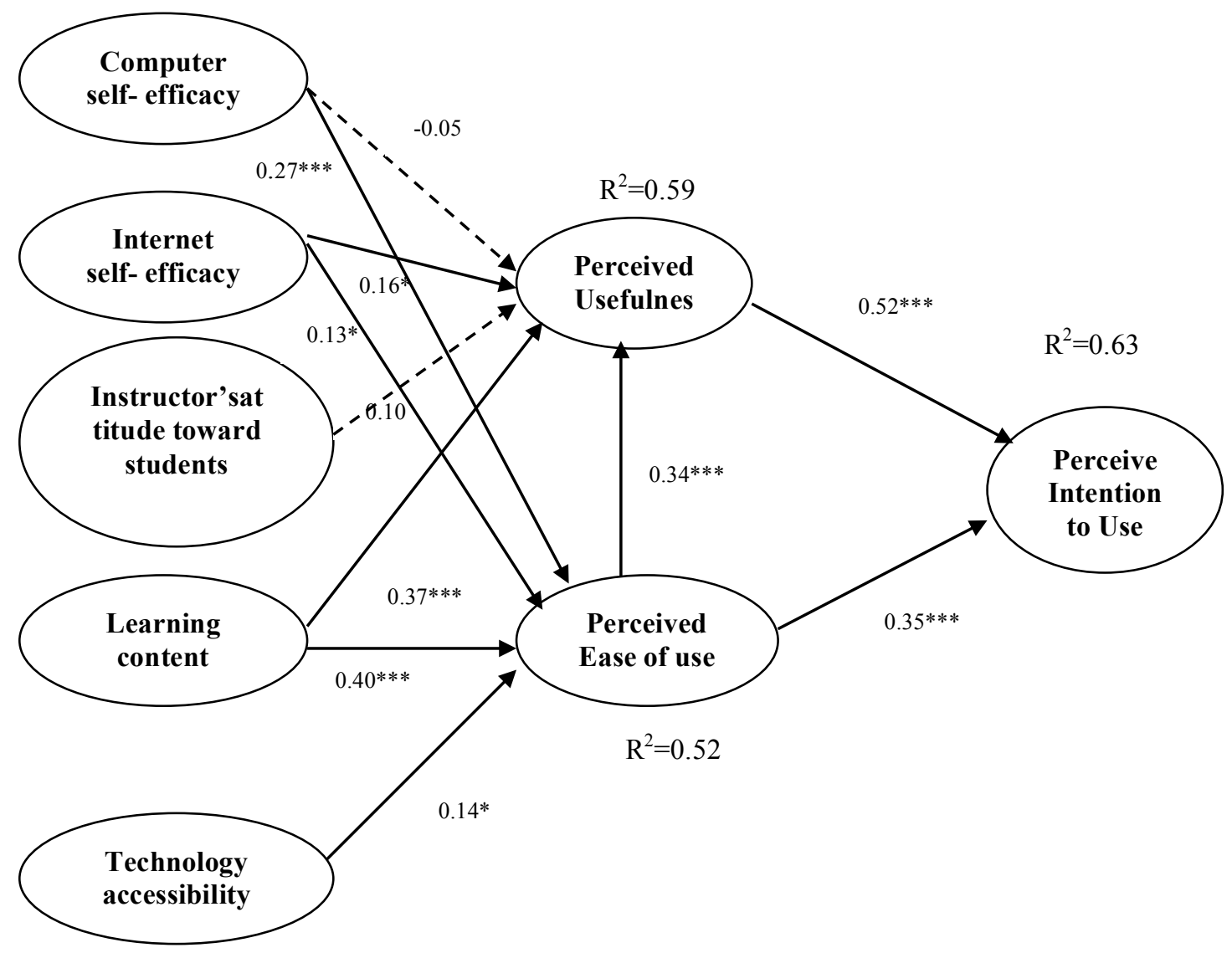

Figure 2.Path analysis of the structural model

\section{Discussion and implications}

We developed an extended TAM by incorporating the external variables observed to be the primary influential factors in enhancing e-learning acceptance in Indonesia's higher education context. Those factors were computer self-efficacy, internet self-efficacy, instructor's attitude toward students, learning content, and technology accessibility. Our study results are consistent with numerous prior TAM studies, indicating that both PEOU and PU are crucial determinants for technology acceptance (e.g., Davis, 1989; Igbaria et al., 1997; Gefen \& Straub, 1997, 2000; Venkatesh \& Davis, 2000; Gefen, 2003; Ong et al., 2004; Lee, 2006; Ong \& Lai, 2006; Hussein et al., 2007; Park et al., 2009). We found PU to have more predictive power than PEOU on PIU of an e-learning system. This result implies that PU is the main determinant of e-learning acceptance. PEOU also demonstrated an indirect effect on PIU through PU, which indicates that students tend to adopt e-learning systems if they perceive them to be easy to use.

We recall critical reviews of TAM (Legris et al., 2003; Wu \& Wu, 2005), which have argued the need to incorporate other external and internal variables to provide a comprehensive view of IT adoption behavior. We also responded to calls for TAM to integrate factors related to human change processes to provide more accurate explanations (Csikszentmihalyi, 1993; Cheng, 2011). We provide the external variables of individual and systematic characteristics of the TAM model to further the research. Previous studies on student acceptance of e-learning systems in higher education have focused on the characteristics of students, such as exploring e-learning concepts among beginning users; course context, such as teaching methods; learning context, such as student perceptions of teaching quality and work quantity; student approaches to learning, in what they do and why they approach learning in particular ways, and the quality of their learning outcomes (Ramsden, 2002; Ellis, Ginns \& Piggott, 2009). We show that the variation in how students accept e-learning is related to their self-efficacy regarding computers and the internet, what they think they are learning and the influence of instructor 
characteristics, and learning content and technology accessibility. We add to this research by considering individual and system characteristics as crucial factors between student approaches to e-learning and their acceptance of this technology.

For individual characteristics of TAM external variables, we found that although computer self-efficacy did not significantly affect PU, it did significantly affect PEOU. This may be because people's confidence in their technology-related knowledge and abilities is associated with their judgment of the ease of usage of the system (Madorin\&Iwasiw, 1999). We provide empirical evidence that PEOU is more closely associated with computer self-efficacy than is PU. As hypothesized, internet self-efficacy significantly influences PEOU. This result supports previous studies indicating that Internet self-efficacy is a prominent factor affecting PEOU, and, in turn, influencing PIU (Eastin, 2002; Hsu \& Chiu, 2004; Roca et al., 2006; Ong \& Lai, 2006). Our findings suggest that instructors and e-learning system designers might wish to consider providing training in an attempt to improve people's Internet self-efficacy, resulting in higher e-learning acceptance. For the systematic characteristics of TAM external variables, our study revealed non-significant relationships between instructor's attitude toward students and PU of e-learning systems. According to Hussein et al. (2007), in contrast to developed countries, in Indonesia, instructor characteristics are not dominant factors, possibly because most e-learning implementation in Indonesia is conducted asynchronously (Soekartawi, 2005). According to the ASTD e-learning glossary (2011), asynchronous learning is learning in which interaction between instructors and students occurs intermittently with a time delay. For example, e-mail, blogging, and self-paced courses are taken through the Internet or from CD-ROMs with Q\&A mentoring. In contrast, synchronous learning is a real-time, instructor-led online learning event in which all participants are logged on simultaneously and communicate directly with each other. Interaction may occur through audio or videoconferencing, internet telephone, or two-way live broadcasts. In Indonesia, virtual classes between instructor and students using synchronous methods are seldom conducted, likely because of internet connectivity issues. Thus, instructor's attitude toward students is not sufficiently strong to predict PU. We also determined learning content to be a significant predictor for both PU and PEOU. This result is consistent with the findings of Pituch and Lee (2006), that learning content as part of system functionality exerts a positive effect on PEOU and PU. Hussein et al. (2007) observed that the design and layout of an e-learning management system has a positive effect on student acceptance of online learning. Their study results indicate that learning content has more predictive power regarding e-learning acceptance than do other external variables. Thus, we concluded that instructors and web design managers should focus more attention on developing well-designed learning content. A well-designed e-learning website could facilitate the interactive capacity of course content between students and instructor. In this case, the learning process would work properly to maximize the level of adoption success. As indicated in these results, technology accessibility is a significant predictor of e-learning acceptance in Indonesia. Previous studies have also observed that perceived accessibility is a crucial determinant of the frequency of using information sources (O'Reilly, 1982; Culnan, 1983). For e-learning developers from developing countries, problems regarding technology accessibility, such as electricity, internet connections, and computer availability remain. Our study result strengthens the argument made in a prior study by Hussein et al.(2007) that the technology factor exerts a significant influence on the PEOU of an e-learning system.

Our study findings have various implications for research and practice. The implications for researchers indicate that the individual characteristics of internet self-efficacy and computer self-efficacy play crucial roles in affecting user beliefs about ease of use. One possible explanation for this may be attributed to motivational theory. Self-efficacy may be considered an intrinsic motivational factor that could help university students self-regulate their motivation toward e-learning. Bandura's social motivational theory (1994) asserts that higher self-efficacy results in a more active learning process. Second, we observed the system characteristics of learning content and technology accessibility to be strong antecedents of ease of use and critical to the success of an e-learning system. We observed learning content to be the strongest antecedent of PU and PEOU in our research model. Third, our study findings contribute to the understanding of user acceptance of an e-learning system and lend support to TAM research findings in that PU and PEOU are critical variables affecting acceptance. Our study result also represents a vital contribution to TAM, suggesting a model for addressing several antecedents of PU and PEOU constructs.

We contribute to practice implications by clarifying methods to enhance student acceptance of e-learning systems in the higher education context. We first show that both individual characteristics, computer selfefficacy and internet self-efficacy, play a crucial role by indirectly affecting PIU of e-learning. Therefore, 
educators and managers should make every effort to boost the e-learning self-efficacy of university students. Specifically, instructors may apply multimedia to facilitate the absorption of learning content easily (Lee, Cheung \& Chen, 2005; Lee, 2006; Cheng, 2011). Furthermore, instructors may use online chat rooms and discussion boards to interact with students to solve their learning problems via e-learning systems and to make them feel comfortable in the virtual learning environment (Chang \& Wang, 2008; Lee et al., 2005; Cheng, 2011). Because PU is the most crucial antecedent of behavioural intention, educators could increase student usage intention by improving their understanding of how an e-learning system enhances academic performance. Educators can also establish user-friendly software (Quinn, 1995) and create a relaxing atmosphere without time pressure to reduce student anxiety toward computers or the internet (Cheng, 2011).

Second, we determined that system characteristics, including learning content and technology accessibility, significantly influence learner acceptance behaviours. Learning content, which encompasses both the subject content as well as the pedagogical design of learning activities for students, should be a critical issue during e-learning system design because users are more willing to use technology that pertains to their needs. In practice, we suggest that e-learning designers improve learning content because this factor is a strong predictor of PU and PEOU, which recalls Park (2009), who suggested that managers and developers develop more user-friendly and user-oriented e-learning content. This type of system helps to change user perceptions and foster greater satisfaction levels, which encourages students to further use e-learning positively. Moreover, designing creative games and incorporating heuristic methods into learning content can enhance students' interest in learning via the e-learning system (Cheng, 2011). For technology accessibility, we observed that students in Indonesian universities continue to encounter connectivity problems. Similarly to other developing countries, Indonesia faces infrastructure development problems. Thus, it is necessary for universities to support infrastructure development to improve student accessibility to e-learning systems.

Third, our research focus on implementing e-learning innovations in higher educational institutions appears significant when universities are undergoing transformational change. Our research indicates that e-learning systems require mature ICT technology and full support from overall educational management structures that shape the learning environment. Except for discussing the individual characteristic of elearners, our research reveals that systematic characteristics of the e-learning system should be considered to enlighten the e-learning adoption system, which is the current challenge within the university context (Casanovas, 2010). For universities to promote e-learning they require a well-designed infrastructure and training support system. Although the research context is Indonesia, a cultural understanding of how internet technology of e-learning exported from the west to meet socio-cultural changes when adopting these technologies in Asia is enlightening (Shah, 2010; Wills, 2012). This implies that current highereducational environments have always been international in scope. Previous research has indicated that cultural differences exist between countries that are e-learning providers (such as Australia) and elearning recipients such as China and the Arab states (McFarlane, 2011). In Australia, the university environment continues to be more culturally diverse because it has been noticeably influenced by migration in recent decades, particularly from Asia (McFarlane, 2011). The implication of this research in Indonesia for international education providers such as those in Australia, is that the cultural context of international students should be considered when presenting materials in an e-learning environment. The learning content in the e-learning system or approaches to enhance student self-efficacy should acknowledge the cultural differences between students and be constructed to better accommodate their needs. Thus, we extend the Indonesian higher-education context and provide broader practice and policy implications for international higher education.

\section{Conclusions and limitations}

In summary, the findings of this study suggest that both the key variables (PU and PEOU) and external variables (computer self-efficacy, internet self-efficacy, learning content, and technology accessibility) should be considered as important factors in the process of designing, implementing, and operating elearning systems in Indonesia. In particular, the individual characteristics that motivate users to adopt elearning systems (computer self-efficacy and internet self-efficacy), and the system characteristics that support e-learning activities (learning content and technology accessibility) are critical in increasing students' behavioural intention to adopt e-learning systems. Another interesting result is that the instructor's attitude toward students is not a significant predictor in a developing country. This is because 
most e-learning implementation is still conducted through asynchronous learning, and virtual classes between instructor and students using synchronous methods are seldom conducted. Finally, utilizing the extended model as a theoretical framework, this study assists practitioners and researchers in gaining a more positive perspective on users' acceptance behaviours toward e-learning systems.

The limitations of this study consist of three main issues. First, the findings and their implications presented here were obtained from a single kind of organization, namely, university. Thus, because elearning in Indonesia is a relatively new topic for IT researchers, caution is necessary when generalizing our findings to other user groups or different organizational contexts. Second, responses to this study were voluntary and thus inevitably subject to self-selection biases. Consequently, users who were interested in, had used, or were currently using e-learning may have been more likely to respond to our online survey. To resolve this issue, future research efforts should be conducted to test the proposed model using a random sampling approach. Third, there may be a need to search for additional variables that will improve our predictability to determine the factors that affect the learners' acceptance of elearning systems. Future researchers can investigate other variables, such as the characteristics of learning management systems (LMSs). For instance, students' perception and attitude toward the LMS, including the design of interface, the communication capabilities of the learning system, and media support, need to be examined since technological advances offer rich learning possibilities which may affect the learners' adoption behaviour (Tselios, Daskalakis \& Papadopoulou, 2011). As derived related works examining acceptance of e-learning, the instructor's attitude towards technology (IMS) may influence the use of the type and quality of information technology (Ruiz-Mercader, Merono-Cerdan, \& Sabater-Sanchez, 2006; Saadé, Nebebe \& Tan, 2007; Ahmed, 2010). Thus, deep understanding of such issues is required in order to provide a clear understanding of how IMS influences learners' acceptance of e-learning.

\section{References}

Abbad, M. M., Morris, D., \& Nahlik, C. D. (2009). Looking under the bonnet: Factors affecting student adoption of e-learning systems in Jordan. International Review of Research in Open and Distance Learning, 10(2), 1-24.

Ahmed, H. M. S. (2010). Hybrid e-learning acceptance model: learner perceptions. Decision Sciences Journal of Innovative Education, 8(2), 313-346.

Ali, M. (2004). e-Learning in the Indonesian Education System. Paper presented at Seminar-Workshop on E-Learning: The Seventh Programming Cycle of APEID Activities, 30 August - 6 September 2004 in Tokyo and Kyoto, Japan.

Andersson, A., \& Grönlund, Å. (2009). A conceptual framework for e-learning in developing countries: A critical review of research challenges. The Electronic Journal on Information Systems in Developing Countries, 38(8), 1-16.

ASTD (The American Society for Training \& Development). (2011). e-learning glossary. Retrieved from http://www.astd.org/LC/glossary.htm.

Bandura, A. (1994). Self-efficacy. In V. S. Ramachaudran (Ed.), Encyclopedia of human behavior, $4^{\text {th }}$ ed., (pp. 71-81). New York, NY: Academic Press.

Barker, A. (2003). Faculty development for teaching online: Educational and technology issues. The Journal of Continuing Education in Nursing, 34(6), 273-278.

Basuki, S.L. (2007). IT and education, the case study of e-learning in Indonesia. Paper presented, CONSAL Meeting, Manila, Philippines.

Blake, M. B., \& Butcher-Green, J. D. (2009). Agent-customized training for human learning performance enhancement.Computers \& Education, 53(3), 966-976.

Brislin, R. W. (1980). Translation and content analysis of oral and written material.In H. C. Triandis, \& J. W. Berry (Eds.), Handbook of cross-cultural psychology (pp. 389 - 444). Boston: Allyn\& Bacon.

Brown, I.T.J. (2002). Individual and technology factors affecting perceived ease of use of web-based learning technologies in a developing country. The Electronic Journal on Information Systems in Developing Countries, 9(5), 1-15.

Burkhardt, M.E., \& Brass, D.J. (1990). Changing patterns or patterns of change: The effects of a change in technology on social network structure and power. Administrative Science Quarterly, 35(1), 104127.

Casanovas, I. (2010). Exploring the current theoretical background about adoption until institutionalization of online education in universities: Needs for further research. Electronic Journal of e-Learning, 8(2), 73 -84. 
Chang, H.H., \& Wang, I.C. (2008). An investigation of user communication behavior in computer mediated environments. Computers in Human Behavior, 24(5), 2336-2356.

Chau, P. Y. K. (1997). Re-examining a model for evaluating information center success using a structural equation modeling approach. Decision Sciences, 28(2), 309-334.

Cheng, Y. M. (2011). Antecedents and consequences of e-learning acceptance.Information Systems Journal, 21(3), 269-299.

Christensen, E. W., Anakwe, U. P., \& Kessler, E. H. (2001). Receptivity to distance learning: The effect of technology, reputation, constraints, and learning preferences. Journal of Research on Computing in Education, 33(3), 263-279.

Collis, B. (1995). Anticipating the impact of multimedia in education: Lessons from the literature. Computers in Adult Education and Training, 2(2), 136-149.

Compeau, D.R. \& Higgins, C.A. (1995). Computer self-efficacy: Development of a measure and initial test. MIS Quarterly, 13(3), 319-340. 19(2), 189-211

Compeau, D.R., Higgins, C. A., \& Huff, S. (1999). Social cognitive theory and individual reactions to computing technology: A longitudinal study. MIS Quarterly,23(2), 145-158.

Csikszentmihalyi, M. (1993). The evolving self: A psychology for the third millennium. New York: Harper Collins.

Culnan, M. J. (1983). Environmental scanning: The effects of task complexity and source accessibility on information gathering behavior. Decision Sciences, 14(2), 194-206.

Davis, F.D., (1989). Perceived usefulness, perceived ease of use, and user acceptance of IT.MIS Quarterly, 13(3), 319-340.

Eastin, M. S. (2002). Diffusion of e-commerce: An analysis of the acceptance of four e-commerce activities. Telematics and Informatics, 19(3), 251-267.

Eastin, M. S., \& LaRose, R. (2000). Internet self-efficacy and the psychology of the digital divide. Journal of Computer Mediated Communication, 6(1) Retrieved from http://jcmc.indiana.edu/vol6/issue1/eastin.html.

Ellis, R .A., Ginns, P., \& Piggott, L.(2009).E-learning in higher education: Some key aspects and their relationship to approaches to study. Higher Education Research \& Development, 28( 3), 303-318.

Engelbrecht, E. (2005). Adapting to changing expectations: Postgraduate students' experience of an elearning tax program. Computers \& Education, 45(2), 217-229.

Fenech, T. (1998). Using perceived ease of use and perceived usefulness to predict acceptance of the World Wide Web. Computer Networks and ISDN Systems, 30(1-7), 629-630.

Fornell, C., \& Larcker, D. F. (1981). Evaluating structural equation models with unobservable variables and measurement error. Journal of Marketing Research,18(1), 39-50.

Gefen, D. (2003). TAM for just plain habit: A look at experienced online shoppers. Journal of Organizational and End User Computing, 15(3), 1-13.

Gefen, D., \& Straub, D.W. (1997). Gender difference in the perception and use of e-mail: An extension to the technology acceptance model. MIS Quarterly,21(4), 389-400.

Gefen, D., \& Straub, D.W. (2000). The relative importance of perceived ease of use in IS adoption: a study of e-commerce adoption. Journal of the Association for Information Systems, 1(1), 1-28.

Graham, P. S. (1995). Requirements for the digital research libraries.College and Research Libraries, 56(4), 331-339.

Hair, J. F., Jr., Anderson, R. E., Tatham, R. L., \& Black, W. C. (1998). Multivariate data analysis(5th ed.). New Jersey: Prentice-Hall. USA

Harter, S. P., \& Kim, H. J. (1996). Accessing electronic journals and other e-publications: An empirical study. College and Research Libraries, 57(5), 440-456.

Hayashi, A., Chen, C., Ryan, T., \& Wu, J. (2004). The role of social presence and moderating role of computer self-efficacy in predicting the continuance usage of e-learning systems, Journal of Information Systems Education, 15(2), 139-154

Hsu, MH., \& Chiu, C.M. (2004). Predicting electronic service continuance with a decomposed theory of planned behaviour. Behaviour \&Information Technology, 23(5), 359-373.

Hussein R., Aditiawarman, U., \& Mohamed N. (2007).E-learning acceptance in a developing country: A case of the Indonesian open university. Presented at: German e-Science Conference. 2007, BadenBaden, Germany, May2-4, 2007

Igbaria, M., Zinatelli, N., Cragg, P., \& Cavaye, L.M. (1997).Personal computing acceptance factors in small firms: A structural equation model. MIS Quarterly, 21(3), 279-305. 
Igbaria, M., \& Ivari, J. (1995). The effects of self-efficacy on computer usage. Omega International Journal of Management Science, 23(6), 587-605.

Jiang, J. J., Klein, G., \& Carr, C. L. (2002). Measuring information system service quality: SERVQUAL from the other side. MIS Quarterly, 26(2), 145-166.

Joo, Y. J., Bong, M., \& Choi, H. J. (2000). Self-efficacy for self-regulated learning, academic selfefficacy, and internet self-efficacy in web-based instruction. Educational Technology Research and Development, $48(2), 5-17$.

Kelly, J. (2001, June 6). E-learning on course for strong growth. Financial Times. Retrieved 30 May 2013 from http://specials.ft.com/ftit/june2001/FT3F80T0JNC.html.

Kelly, T., \& Bauer, D. (2004).Managing intellectual capital via e-learning at Cisco. In C. Holsapple (Ed.),Handbook on knowledge management 2: Knowledge directions(pp. 511-532). Springer, Berlin, Germany.

Kinash, S., Brand, J., \& Mathew, T. (2012).Challenging mobile learning discourse through research: Student perceptions of Blackboard Mobile Learn and iPads. Australian Journal of Educational Technology, 28(4), 639-655.

Kuntoro, R. D,. \& Al-Hawamdeh, S. (2003). E-learning in higher educational institutions in Indonesia. Journal of Information \& Knowledge Management, 2(4), 361-374.

Lau, S.H., \& Woods, P.C. (2009). Understanding learner acceptance of learning objects: The roles of learning object characteristics and individual differences. British Journal of Educational Technology, 40(6), 1059-1075.

Lee, B. C., Yoon, J. O.,\& Lee, I. (2009). Learners' acceptance of e-learning in South Korea: Theories and results. Computers \& Education, 53(4), 1320-1329.

Lee, M. K. O., Cheung, C. M. K.,\& Chen, Z. (2005). Acceptance of internet-based learning medium: The role of extrinsic and intrinsic motivation. Information \& Management, 42(8), 1095-1104.

Lee, Y.C. (2006). An empirical investigation into factors influencing the acceptance of an e-learning system. Online Information Review,30(5), 517-541.

Legris, P., Ingham, J., \& Collerette, P. (2003). Why do people use information technology? A critical review of the technology acceptance model.Information and Management, 40(3), 191-204.

Lim H., Lee S.G., \& Nam K. (2007). Validating e-learning factors affecting training effectiveness. International Journal of Information Management, 27(1), 22-35.

Lin, J. C., \& Lu, H. (2000). Towards an understanding of the behavioral intention to use a website. International Journal of Information Management, 20(3), 197-208.

Madorin, S., \& Iwasiw, C. (1999).The effects of computer-assisted instruction on the self-efficacy of baccalaureate nursing students.Journal of Nursing Education,38(6), 282-285.

McFarlane, P. S. (2011). Determining student preference for a culturally specific e-learning website(Doctoral dissertation).University of Wollongong. School of Information Systems and Technology, University of Wollongong. Retrieved from http://ro.uow.edu.au/ theses/3409.

Ngai, E. W. T., Poon, J. K. L., \& Chan, Y. H. C. (2007). Empirical examination of the acceptance of WebCT using TAM.Computers and Education, 48(2), 250-267

Okazaki, S., \& dos Santos, L. M. R. (2012). Understanding e-learning adoption in Brazil: Major determinants and gender effects. International Review of Research in Open and Distance Learning, 13(4), 91-106.

Ong, C. S., Lai, J. Y., \& Wang, Y. S. (2004). Factors affecting engineers' acceptance of asynchronous elearning systems in high-tech companies.Information \& Management,41(6), 795-804.

Ong, C. S., \& Lai J. Y. (2006). Gender differences in perceptions and relationships among dominants of e-learning acceptance. Computers in Human Behavior, 22(5), 816-829.

O'Reilly, C. A. (1982). Variations in decision makers' use of information sources: The impact of quality and accessibility of information. Academy of Management Journal, 25(4), 756-771.

Pan, C.C., Sivo, S., \& Brophy, J. (2003). Student's attitude in a web-enhanced hybrid course: A structural equation modeling inquiry. Journal of Educational Media \& Library Sciences, 41(2), 181194.

Pannen, P., \&Abubakar. (2005). Designing e-learning: Shouldn't we be ready? Proceedings of the Second International Conference on e-Learning for Knowledge-Based Society, August 4-7, 2005, Bangkok, Thailand, 241-246.

Park N., Roman R., Lee S., \& Chung, J. E. (2009). User acceptance of a digital library system in developing countries: An application of the Technology Acceptance Model. International Journal of Information Management, 29(3), 196-209. 
Park, S. Y. (2009). An analysis of the Technology Acceptance Model in understanding university students' behavioral intention to use e-learning. Educational Technology \& Society, 12(3), 150-162.

Picciano, A. G. (2001). Distance learning: Making connections acrossvirtual space and time. New Jersey: Prentice Hall.

Pituch, K. A., \& Lee, Y. K. (2006). The influence of system characteristics on e-learning use.Computers \& Education, 47, 222-244.

Poon, W. C., Low, K. L., \& Yong, D. G. (2004).A study of web-based learning (WBL) environment in Malaysia.The International Journal of Educational Management, 18(6), 374-385.

Priyanto, (2007). Redesign of e-learning development in Indonesia. Paper presented at Seminar of Faculty of Engineering, Yogyakarta State University, Indonesia.. Retrieved from: http://www.voced.edu.au/content/ngv45802.

Purnomo, S. H., \& Lee, Y. H. (2010). An assessment of readiness and barriers towards ICT program implementation: Perceptions of agricultural extension officers in IndonesiaInternational Journal of Education and Development using Information and Communication Technology, 6(3), 19-36.

Quinn, B. (1995). Reducing stressful aspects of information technology in public services. Public and Access Services Quarterly, 1(4), 1-34.

Ramsden, P. (2002). Learning to teach in higher education (2nd ed.). London: Routledge.

Roca, J. C., Chiu, C. M., \& Martinez, F. J. (2006). Understanding e-learning continuance intention: An extension of the Technology Acceptance Model. International Journal Human-Computer Studies, 64(8), 683-696.

Ruiz-Mercader, J., Merono-Cerdan, A. L., \& Sabater-Sanchez, R. (2006). Information technology and learning: Their relationship and impact on organizational performance in small businesses. International Journal of Information Management, 26(1), 16-29.

Saadé, R. G.,\&Bahli, B. (2005). The impact of cognitive absorption on perceived usefulness and perceived ease of use in on-line learning: An extension of the Technology Acceptance Model. Information and Management,42(2), 317-327.

Saadé, R. G., Nebebe, F., \& Tan, W. (2007).Viability of the Technology Acceptance Model in multimedia learning environments: A comparative study. Interdisciplinary Journal of Knowledge and Learning Objects, 3(1), 175-184.

Serwatka, J. A. (1999). Internet distance learning: How do I put my course on the web?,Technology Horizons in Education/The Journal,26(10), 71-75.

Shah, C. (2010), Collaborative Information Seeking: A Literature Review, in Anne Woodsworth (ed.) Advances in Librarianship (Advances in Librarianship, Volume 32) Emerald Group Publishing Limited, pp. $3-33$.

Seyal, A.H., Rahman, M.N.A., \& Rahim, M.M. (2002). Determinants of academic use of the internet: A structural equation model. Behaviour \& Information Technology, 21(1), 71-86.

Soekartawi, (2005). Constraints in implementing 'e-learning' using WebCT: Lessons from the SEAMEO Regional Open Learning Center. Malaysian Online Journal of Instructional Technology,2(2), 97-105.

Tselios, N., Daskalakis, S., \&Papadopoulou, M. (2011). Assessing the acceptance of a blended learning university course.Educational Technology \& Society, 14(2), 224-235.

Venkatesh, V. (2000). Determinants of perceived ease of use: Integrating control, intrinsic motivation, and emotion into the technology acceptance model. Information Systems Research, 11(4), 342-365.

Venkatesh, V., \& Davis, F. D. (1996). A model of the antecedents of perceived ease of use: Development and test. Decision Sciences, 27(3), 451-481.

Venkatesh, V., \& Davis, F. D. (2000). A theoretical extension of the technology acceptance model: Four longitudinal field studies. Management Science,46(2), 186-204.

Venkatesh, V., \& Morris, M. G. (2000). Why don't men ever stop to ask for directions? Gender, social influence, and their role in technology acceptance and usage behavior.MIS Quarterly,24(1), 115-139.

Venkatesh, V., Morris, M. G., Davis, G. B., \& Davis, F. D. (2003). User acceptance of information technology: Toward a unified view. MIS Quarterly, 27(3), 425-478.

Volery, T., \& Lord, D. (2000). Critical success factors in online education. The International Journal of Educational Management, 14(5), 216-223.

Welsh, E. T., Wanberg, C. R., Brown, K. G., \& Simmering, M. J. (2003). E-learning: Emerging uses, empirical results and future directions. International Journal of Training and Development, 7(4), 245-258.

Wills, S. (2012). Role-based e-learning for university students: A comparison of Australian, American, 
British and Singapore designs, Journal of Comparative Education, 73, 91-129.

Wixom, B. H., \& Todd, P. A. (2005). A theoretical integration of user satisfaction and technology acceptance.Information Systems Research, 16(1), 85-102.

Wu, I. L., \& Wu, K. L. (2005). A hybrid technology acceptance approach for exploring e-CRM adoption in organizations.Behaviour \& Information Technology, 24(4), 303-316.

Yuen, A. H. K., \& Ma, W. W. K. (2008). Exploring teacher acceptance of e-learning technology. AsiaPacific Journal of Teacher Education, 36(3), 229-243.

Yuhetty, H. (2003). Use of ICT in education in Indonesia. A paper submitted for the experts' group meeting for documenting experiences in the use of Education and SchoolNet operation, Bangkok. Retrieved from: http://unpan1.un.org/intradoc/groups/public/documents/apcity/unpan011286.pdf

Zhang, Y. \& Estabrook, L. (1998). Accessibility to internet-based electronic resources and its implications for electronic scholarship. Proceedings of the ASIS Annual Meeting. Pittsburgh, USA

Corresponding author: Sutrisno Hadi Purnomo, sutrisno.purnomo@gmail.com

Australasian Journal of Educational Technology (C) 2014.

Please cite as: Lee, Y-H., Hsiao, C., \& Purnomo, S.H. (2014). An empirical examination of individual and system characteristics on enhancing e-learning acceptance. Australasian Journal of Educational Technology, 30(5), 561-579. 